\title{
The Effectiveness of Constructivist Learning Using Guided Discovery Models on The Concept of A Regulatory System for Curiosity and Anti- Narcotics Attitudes
}

\author{
Sulasfiana Alfi Raida ${ }^{1 *}$, Didi Nur Jamaludin ${ }^{2}$ \\ ${ }^{1,2}$ Institut Agama Islam Negeri Kudus, Jl. Conge Ngembalrejo PO BOX 51, Kudus, Indonesia \\ *Correspondence: sulasfiana@iainkudus.ac.id
}

\begin{tabular}{ll}
\hline Keywords: & Tbstract \\
Guided discovery & This research aimed to analyze the effectiveness of constructivist learning using \\
guided discovery models on the concept of a regulatory system for curiosity and anti- \\
Curiosity & narcotics attitudes. This research used a quasi-experimental and pre-experimental \\
Anti-narcotics attitude & Sesign. The population was all of the 4th semester MIA classes of SMA Negeri 1 \\
& Sampling technique. MIA 2.4 and 5.4 as the experimental group and MIA 3.4 and 4.4 \\
& as the control group. The data in this research were collected by the scale of curiosity \\
and anti-narcotics attitude. Data were analyzed with descriptive analyzed and t-test. & The result showed as follows: there is a significant difference at the end of the \\
& curiosity and anti-narcotics attitude of constructivist learning using guided discovery \\
& model compared with direct instruction model learning; the average of student's \\
& curiosity and anti-narcotics attitude score $\geq 3,00$ on constructivist learning using \\
guided discovery model. It is concluded that constructivist learning using a guided \\
discovery model is effectively completed learning outcomes of the curiosity and anti- \\
narcotics attitude on the regulatory system concept.
\end{tabular}

To cite this article:

Raida, S.A., Jamaludin, D.N. (2020). The Effectiveness of Constructivist Learning Using Guided Discovery Models on The Concept of A Regulatory System for Curiosity and AntiNarcotics Attitudes. Thabiea: Journal of Natural Science Teaching, 3(1), 41-50.

\section{Introduction}

Learning about the regulatory system concept requires students to learn the working mechanism of the human regulatory system consisting of the nervous system, sensory system, and endocrine system. Alfiraida (2018) in his research stated that the concept for the regulatory system was one of the concepts considered difficult by students and teachers of SMA/MA throughout Salatiga City. This shows that students have difficulty achieving the learning objectives of the regulatory system concept.

The regulatory system concept is broadly divided into three sub-concepts in the 2013 Curriculum, namely the nervous system, endocrine system, sensory system, and the influence of drugs (narcotics, psychotropic substances, and additives) on the regulatory system (Permendikbud, 2014a). Mastery of the regulatory system concept can be obtained if students can link the knowledge of the nervous system, sensory, and endocrine concept in coordination to produce activity, and can evaluate the dangers of consuming drugs to the regulatory system. Therefore, the learning regulatory system concept should not be studied separately so that students can master the overall regulatory system concept. This is specified in basic 
competencies which are the minimum competencies students must achieve in learning (Permendikbud, 2014b).

Based on basic competencies in the regulatory system concept, students are not only encouraged to understand the concept but are also encouraged to develop the analysts and evaluative thinking skills towards the problems related to the regulatory system concept. In addition to knowledge competencies, learning regulatory systems also emphasize students to develop attitude competencies. One of the attitudes that can be developed in the learning of regulatory systems is the anti-narcotics attitude.

In the regulatory system learning, students are asked to campaign for anti-narcotics attitudes to the public. Of course, students are required to develop anti-narcotics attitudes in themselves first. The development of competence in anti-narcotics attitudes refers to the affective domain (attitude) by Bloom and Krathwohl (1964). This domain is related to the emotional component in learning and revolves around the desire to receive information that is integrated into beliefs, ideas, and convictions (Kennedy et al., 2007). As for the modification of anti-narcotics attitudes that students can develop, among others; 1. Be aware of drug cases/dangers in the surrounding environment; 2. Shows the role and participation in the community to anticipate the dangers of drug use; 3. Giving value or price to drug cases/dangers which are shown with concern or behavior; 4. Organizing different values and solving problems/cases of drugs in the surrounding environment; 5 . Have a system of values on beliefs, ideas, anti-narcotics attitudes in controlling behavior consistently.

Anti-narcotics attitudes can be developed if students can get the meaning of learning. The meaning is obtained by students after students are able to construct and find knowledge in learning. Constructivist learning is one of the learning strategies that can be used to build knowledge. Students construct their own meaning, new knowledge is obtained from previous knowledge, learning develops through social interaction, and through authentic assignments. Learning starts from experience to knowledge, not vice versa. Students are actively involved in finding meaning, enthusiastic, productive, motivated in class, more confident, and able to apply skills and knowledge to further activities (Raida, 2017).

The teacher in high school learning acts as a facilitator. The teacher provides full guidance to students to achieve learning goals. Therefore, the learning design developed by the teacher should enable a deep understanding of the concepts, principles, and strategies of learning that are targeted, and use learning methods that are accompanied by guidance.

Guided discovery is one of the learning models that encourage students to construct knowledge through teacher guidance (Raida, 2017). Guidance in the form of presenting problems related to learning concept can be seen in the following guided discovery stages: 1) the introduction and review stage, where the teacher presents examples of daily problems; 2) the open stage, that is, the teacher presents additional examples; 3) convergent stage, the teacher presents additional examples and other examples that encourage students to analyze the relationship; 4) closing stages, the teacher asks students to give another example (Jacobsen et al., 2009). Through examples of presenting these problems, the teacher can stimulate student curiosity.

The attitude of curiosity is a curiosity that is characterized by the behavior of trying to know and master the things that want to be studied, seen, and heard in-depth (Salirawati, 2012). Binson (2009) defines curiosity as a tendency to ask questions, investigate, and search 
after gaining knowledge. Anwar (2009) states that curiosity can be seen from the habit of asking about things that are following their field of study. Based on the above opinion it can be understood that curiosity is a desire / high motivation for someone based on information to find new / more in-depth information.

There are two attitudes developed in guided discovery constructivist learning on the regulatory system concept, namely the attitude of curiosity and anti-narcotics attitude. In the 2013 Curriculum public test concepts, students are encouraged to behave scientifically in 2013 learning especially in developing curiosity to improve thinking skills. Therefore the attitude competency emphasized learning the regulatory system concept is curiosity. Also, the basic competency of the regulatory system concept emphasizes students to analyze and evaluate the understanding of the impact of drugs on life, so that the competence of antinarcotics attitudes is developed in the learning of the regulatory system concept.

Based on the description above, the researchers conducted a study to analyze the role of the constructivist learning model guided discovery towards the attitude of curiosity and anti-narcotics attitudes in the high school regulatory system concept. The formulation of the problems in this study include: 1) is there a significant difference in the score of curiosity, and the anti-narcotics attitude score between constructivist learning guided discovery models with learning direct learning models?; 2) Is the average score of students' curiosity and antinarcotics attitudes significantly $\geq 3.00$ in the guided discovery constructivist learning model?.

\section{Method}

This research is an experimental study using a quasi-experimental design and using a pre-experimental design. This research was conducted at SMA Negeri 1 Salatiga.

The population consists of 200 students. The population is divided into seven classes in SMA Negeri 1 Salatiga. The sampling technique used is convenience sampling. This is because the sample has been determined by the biology teacher at the high school so the researcher is not authorized to determine the sample. The samples taken are divided into 2 groups, namely the experimental class and the control class. MIA 2.4 and 5.4 classes are the experimental groups, while MIA 3.4 and 4.4 classes are the control group.

The hypotheses tested in this study are comparative hypotheses and descriptive hypotheses. The formulation of the comparative hypothesis is, $\mathrm{H}_{0}$ : There is no significant difference in attitude scores between the experimental and control groups; Ha: there is a significant difference in attitude scores between the experimental and control groups. The formulation of descriptive hypotheses is, $\mathrm{H}_{0}$ : Average attitude score of students $\geq 3,00$; Ha: Average student attitude score $<3.00$.

Descriptive hypothesis formulation is obtained from the assumption that guided discovery learning can provide high attitude learning outcomes for students. Attitude learning outcomes obtained at the end of learning are compared with the minimum completeness score specified in the 2013 Curriculum, which is a score of 3.00 for attitudes learning outcomes (Permendikbud, 2014b). This analysis was obtained by One Sample T-test parametric statistical analysis technique. 


\section{Results and Discussion}

\section{Learning Outcomes of Curiosity Attitudes}

The results of curiosity attitude learning are obtained from the filling in attitude scale at the beginning and end of learning. The curiosity attitude scores in Table 1 and Table 2 show that the experimental and control groups experienced an increase in scores. The experimental group experienced a much higher increase than the control group. The experimental group increased by 1.25 , while the control group increased by 0.43 (Table 2).

Table 1. Criteria for Student's Curiosity Attitudes

\begin{tabular}{lccccc}
\hline \multirow{2}{*}{$\begin{array}{c}\text { Attitude scale } \\
\text { score }\end{array}$} & Category & \multicolumn{4}{c}{ Total students } \\
\cline { 3 - 6 } & & \multicolumn{2}{c}{ Pre-test } & \multicolumn{2}{c}{ Post-test } \\
\cline { 2 - 6 } & Experimental & Control & $\begin{array}{c}\text { Experimental } \\
\text { class }\end{array}$ & $\begin{array}{c}\text { Control } \\
\text { class }\end{array}$ & class \\
\hline $1,0-1,75$ & L (Low) & 4 & 5 & - & 31 \\
\hline$>1,75-2,5$ & $M$ (Medium) & 51 & 50 & - & 1 \\
\hline$>2,5-3,25$ & $H$ (High) & 2 & - & 17 & 22 \\
\hline$>3,25-4$ & $V H$ (Very High) & - & - & 40 & 1 \\
\hline Total students & & 57 & 55 & 57 & 55 \\
\hline
\end{tabular}

Table 2. Recapitulation of Learning Outcomes of Students' Curiosity Attitudes

\begin{tabular}{|c|c|c|c|c|c|c|c|c|c|c|}
\hline \multirow[b]{2}{*}{ Group } & \multirow[b]{2}{*}{$\mathrm{N}$} & \multicolumn{4}{|c|}{ Pre-test } & \multicolumn{4}{|c|}{ Post-test } & \multirow{2}{*}{$\begin{array}{c}\Delta \\
\text { (Posttest- } \\
\text { pre-test) }\end{array}$} \\
\hline & & $\begin{array}{l}\text { Lowest } \\
\text { score }\end{array}$ & $\begin{array}{l}\text { Highest } \\
\text { score }\end{array}$ & Average & $\begin{array}{c}\text { Std. } \\
\text { deviation }\end{array}$ & $\begin{array}{l}\text { Lowest } \\
\text { score }\end{array}$ & $\begin{array}{l}\text { Highest } \\
\text { score }\end{array}$ & Average & $\begin{array}{c}\text { Std. } \\
\text { deviation }\end{array}$ & \\
\hline Experiment & 57 & 1,46 & 2,54 & 2,16 & 0,21 & 2,88 & 4,00 & 3,41 & 0,25 & 1,25 \\
\hline Control & 55 & 1,42 & 2,35 & 2,05 & 0,21 & 1,54 & 3,42 & 2,48 & 0,32 & 0,43 \\
\hline
\end{tabular}

\section{Learning Outcomes of Anti-Narcotics Attitudes}

Anti-narcotics attitude scores are taken using an attitude scale at the beginning and end of the meeting. Data on anti-narcotics attitude scores are presented in Table 3 and Table 4.

Table 3. Criteria for Students' Anti-Narcotics Attitudes

\begin{tabular}{|c|c|c|c|c|c|}
\hline \multirow{3}{*}{$\begin{array}{c}\text { Attitude } \\
\text { scale score }\end{array}$} & \multirow{3}{*}{ Category } & \multicolumn{4}{|c|}{ Total students } \\
\hline & & \multicolumn{2}{|l|}{ Pre-test } & \multicolumn{2}{|c|}{ Post-test } \\
\hline & & Experimental class & Control class & Experimental class & Control class \\
\hline $1,0-1,75$ & $L$ (Low) & & - & - & \\
\hline$>1,75-2,5$ & $M$ (Medium) & & - & - & \\
\hline$>2,5-3,25$ & $H$ (High) & 4 & 13 & 2 & 23 \\
\hline$>3,25-4$ & $V H$ (Very High) & 53 & 42 & 55 & 32 \\
\hline \multicolumn{2}{|c|}{ Total students } & 57 & 55 & 57 & 55 \\
\hline
\end{tabular}

The results of filling in an attitude scale showed that the experimental and control groups had anti-narcotics attitudes with a minimum score of B (both) before and after learning (Table 1). Both groups experienced increased scores, but the experimental group increased higher than the control group. The experimental group increased by 0.21 , while the control group increased by 0.14 (Table 2 ). 
Table 4. Recapitulation of Learning Outcomes of Students' Anti-Narcotics Attitudes

\begin{tabular}{|c|c|c|c|c|c|c|c|c|c|c|}
\hline \multirow[t]{2}{*}{ Group } & \multirow[b]{2}{*}{$\mathrm{N}$} & \multicolumn{4}{|c|}{ Pre-test } & \multicolumn{4}{|c|}{ Post-test } & \multirow{2}{*}{$\begin{array}{c}\Delta \\
\text { (Posttest- } \\
\text { pretest) }\end{array}$} \\
\hline & & $\begin{array}{l}\text { Lowest } \\
\text { score }\end{array}$ & $\begin{array}{l}\text { Highest } \\
\text { score }\end{array}$ & Average & $\begin{array}{c}\text { Std. } \\
\text { leviation }\end{array}$ & $\begin{array}{l}\text { Lowest } \\
\text { score }\end{array}$ & $\begin{array}{l}\text { Highest } \\
\text { score }\end{array}$ & Average & $\begin{array}{c}\text { Std. } \\
\text { deviation }\end{array}$ & \\
\hline Experiment & 57 & 2,97 & 3,97 & 3,49 & 0,20 & 3,00 & 4,00 & 3,70 & 0,22 & 0,21 \\
\hline Control & 55 & 2,97 & 3,93 & 3,36 & 0,27 & 3,00 & 4,00 & 3,50 & 0,27 & 0,14 \\
\hline
\end{tabular}

\section{Comparative Hypothesis Test Analysis Results}

The recapitulation of student learning outcomes was further analyzed by the Independent T-test parametric analysis technique. This technique is used to find out whether or not there are differences in learning outcomes between the experimental and control groups. The average pre-test score of the curiosity score and the anti-narcotics attitude score in the experimental and control groups differed, amounting to 0.11 ; and 0.13 .

Hypothesis testing using the Independent T-test analysis technique must be preceded by the assumption that both groups have homogeneous variants. The hypothesis proposed in the homogeneity test is as follows.

$\mathrm{H}_{0}$ : Both groups have homogeneous variants.

Ha: Both groups have variants that are not homogeneous.

The homogeneity test using the Levene Test applies that, if the Sig. greater than $\alpha$ (0.05), then $\mathrm{H}_{0}$ is accepted and $\mathrm{Ha}$ is rejected. The Independent T-test analysis technique applies the provision that, if the value of Sig. (2-tailed) $>\alpha(0.05)$, then $\mathrm{H} 0$ is accepted. Homogeneity test results and Independent T-test are presented in Table 5.

Table 5. Results of the Independent T-test Analysis

\begin{tabular}{lrrc}
\hline \multirow{2}{*}{ Gain score } & \multicolumn{2}{c}{ Levene Test } & \multicolumn{2}{c}{ Independent T-test } \\
\cline { 2 - 4 } & Sig. & df & Sig. (2-tailed) \\
\hline Curiosityattitude & 0,855 & 110 & 0,000 \\
\hline Anti-narcotics attitude & 0,687 & 110 & 0,000 \\
\hline
\end{tabular}

Table 5 presents the results of homogeneity test analysis using the Levene Test and Independent T-test on the gain score of anti-narcotics attitudes, and curiosity. Homogeneity test on the gain score on anti-narcotics attitude scores and curiosity scores obtained by Sig. of the three scores $>\alpha(0.05)$, then $\mathrm{H}_{0}$ is accepted. This shows that the assumptions of the two groups have an acceptable homogeneous variant.

Based on Table 5, Sig (2 tailed) scores of the three scores $<\alpha(0.05)$, in the sense that $\mathrm{H}_{0}$ is rejected. So it was concluded that there were differences in attitudes learning outcomes (curiosity attitude scores and anti-narcotics attitudes) in the experimental and control groups.

\section{Descriptive Hypothesis Test Analysis Results}

In addition to testing the comparative hypothesis, this study also tested a descriptive hypothesis using the One-Sample T-test parametric statistical analysis technique using oneparty testing (left) on the post-test scores for each learning outcome. If the value of $t$ arithmetic $\geq \mathrm{t}$ table, then $\mathrm{Ha}$ is rejected and $\mathrm{H}_{0}$ is accepted. Based on Table 6 , the value of the $\mathrm{t}$-count> $\mathrm{t}$-table (1.673) is obtained, then $\mathrm{H}_{0}$ is accepted. These results indicate the average score of curiosity attitudes and anti-narcotics attitude scores of students $\geq 3.00$ (Table 6). 
Table 6. Results of One Sample T-test Analysis

\begin{tabular}{llrrr}
\hline \multicolumn{1}{c}{ Data } & Test Value & $\mathrm{t}$ & $\mathrm{df}$ & Sig. (2-tailed) \\
\hline Curiosityattitude & 3,00 & 12,625 & 56 & 0,000 \\
\hline Anti-narcotics attitude & 3,00 & 24,253 & 56 & 0,000 \\
\hline
\end{tabular}

The results in Table 1 show that the guided discovery learning model provides better curiosity attitudes towards the students. The experimental group experienced significantly higher attitudes than the control group (Table 2). The results of the comparative hypothesis test also showed that there were significant differences in the scores of curiosity attitudes between the two groups (Table 5). Also, the results of the descriptive hypothesis test showed that the average score of curiosity attitudes reached/exceeded the minimum completeness score in the 2013 Curriculum, which was $\geq 3.00$ (Table 6).

The students 'curiosity attitude can be seen in detail from the percentage score of each dimension on filling the students' curiosity scale at the end of the lesson. The curiosity attitude scale developed by Utami (2014) contains several factors that can stimulate students' curiosity attitudes as dimensions in measurement. Factors that can stimulate an attitude of curiosity is because of experiencing complexity, novelty, incongruity, ambiguity, surprise, perplexity, experiencing contradiction, cognitive, changing, conflict, doubt, and lack of clarity. The percentage of the attitude of curiosity of some of these dimensions between the experimental group and the control group is presented in Figure 1.

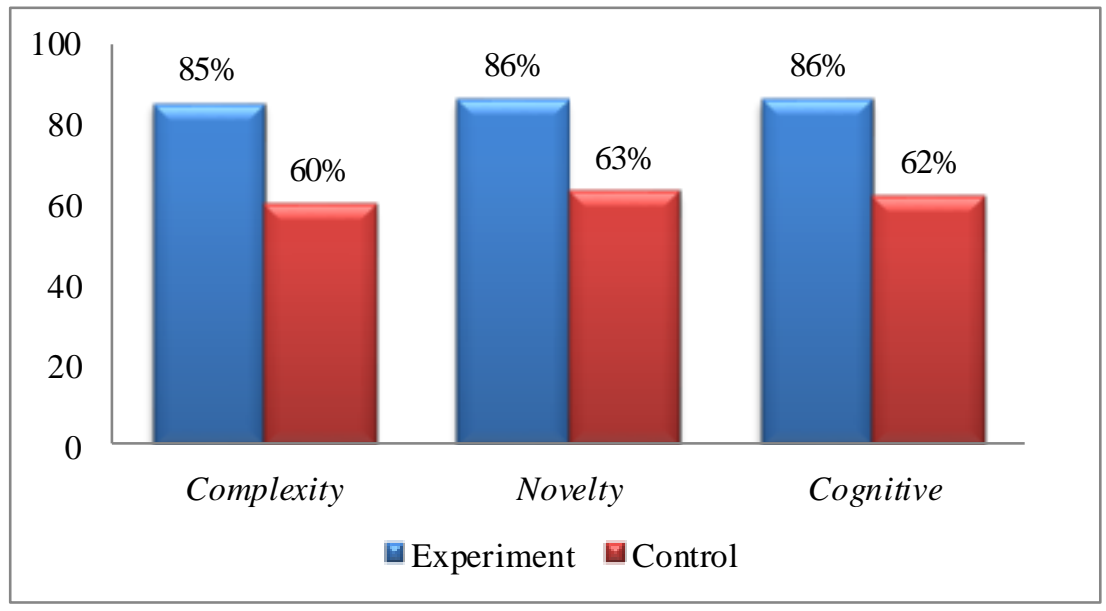

Figure 1. Percentage of students' curiosity attitudes in every aspect.

Based on Figure 1. it appears that students who have an attitude of curiosity through guided discovery learning more than students in learning direct learning models. The high percentage of the attitude of curiosity in the experimental group is shown from the indicators of curiosity in several dimensions above that are met. Indicators of curiosity are students who enjoy learning biology and are challenged to master (complexity dimension); students interested in studying biology, like to be actively involved, and explore the concept (novelty dimension); and students look for a lot of information, study deeper, never give up, analyze the truth, and pay attention to explanations (novelty dimension). 
Examples of phenomena in everyday life presented in learning can stimulate students' curiosity. This attitude can be seen from the emergence of student questions from the presentation of the example in the experimental group. This shows that students need knowledge (cognitive) based on the facts of the phenomenon from the presentation of examples that are often encountered by students. In the control group, the teacher also presents examples that are often encountered by students, but student curiosity is lower than in the experimental group. The low attitude is because in the control group students have obtained the answers they want to know through the teacher's explanation.

In connection with the above, students' curiosity in the experimental group continues to develop at each stage of learning. Students try to gain knowledge of regulatory systems that play a role in producing activities that often do. Students try to find out the truth of the concept of the regulatory system by finding detailed information about everything that is questioned. This is consistent with the statement of Melani et al. (2012) in his research that giving examples in real environments can motivate students to find answers so that students' curiosity attitudes develop through guided discovery learning.

According to Salirawati (2012) students who have high curiosity attitudes in learning have more knowledge than students who are passive in learning. Students who have a high curiosity attitude try to find information until students get the knowledge needed. This is done by students in the experimental group. Students explore as much information as possible to get answers that are considered appropriate until students can master the concepts. Research findings on classical curiosity attitude score data (Table 2) are consistent with the statement. A higher final test score was obtained by the experimental group which had an increased score of high curiosity as well.

The development of a curiosity attitude is developed by the teacher through several stages of learning, namely the introduction and review stages, the open stage, the convergent stage, and the closing stage. In the introduction and review stages. The teacher presents examples of problems in everyday life. Students convey ideas/ideas, questions, and raise problems that are similar to questions based on experience. Anwar (2009) states that the habit of asking shows curiosity in students. Students begin to compare examples with their activities in daily life. This activity indicates that students begin to develop their curiosity in learning.

In the open stage, the teacher presents other examples of problems on the Observation Sheet and Student Worksheets. Students answer the questions in the worksheet by developing an attitude of curiosity. Students find out the answers to worksheets by conducting group discussions, searching for information via the internet, and biology sourcebooks such as Campbell. In this process, students are not allowed to use biology summary books (textbooks) as a reference source to do worksheets. This is because, if students use a student summary book will only move the answers from the book into the LKS answer column, so that students' curiosity attitude is not developed.

In addition to doing worksheets, students also do some examinations related to the regulatory system concept. Observations made by students are guided by the teacher using Observation Sheets. Curiosity attitude of students develops in observation activities. Students compare it with experiences in daily life until students can find the concept of the registration 
system. In line with research Laelasari \& Adisendjaja (2018) said that research activities can develop students' curiosity attitudes so students are motivated to find new concepts.

In the convergent stage, the teacher creates social interaction by asking students to have class discussions. After discussing in groups to do worksheets, students are asked to present their worksheets in front of the class. Other students pay attention to the delivery of answers and compare them with the answers on the worksheets that have been done. The difference in answers to the worksheet encourages students to develop curiosity by giving questions to the group on duty. At this stage, the teacher continues to guide the class discussion. The teacher gives feedback, mediates, and gives an appreciation for students who are active in the activity.

In the closing stages, the teacher asks students to connect the concept concepts from the beginning to the end of learning at each meeting. Students evaluate and reflect on all information and learning processes in which includes the development of an attitude of curiosity.

Learning regulatory system concept in addition to requiring students to master the concept, also requires students to have anti-narcotics attitudes. The experimental and control groups had high anti-narcotics attitudes before learning (Table 3). Both groups experienced a slight increase in attitude scores, but the experimental group had a higher score increase than the control group. Besides, the results of the comparative and descriptive hypothesis test analysis show that guided discovery learning is effective in completing anti-narcotics attitude scores. The results of the comparative hypothesis test showed that there were significant differences in the scores of anti-narcotics attitudes between the two groups (Table 5), while in the descriptive hypothesis test results were obtained that the average score of anti-narcotics attitude scores was $\geq 3.00$ (Table 6 ).

The results of research on anti-narcotics attitudes in both groups showed the ability of students to maintain and develop positive attitudes in avoiding drug consumption. The development of anti-narcotics attitudes starts from the process of gaining knowledge about the regulatory system at the beginning of learning until learning the sub-concept of the drug's influence on the regulatory system. In the experimental and control groups, students not only get assignments to do worksheets on learning the sub-concept, but students also get assignments for anti-narcotics campaigns. This task is adjusted to the basic competencies emphasized by the subconcept. Students apply anti-narcotics knowledge and attitudes through posters, then upload it to social media.

High anti-narcotics attitudes in the experimental and control groups in detail can be seen in the percentage of anti-narcotics attitude scores for each aspect. Some aspects of attitudes contained on the scale of anti-narcotics attitudes, including receiving; responding; valuing; organization; and characterization. The percentage of anti-narcotics attitudes of the experimental and control groups in each aspect is presented in Figure 2.

Figure 2 shows that both groups were able to achieve indicators of anti-narcotics attitudes in each aspect. Students were able to achieve these indicators because students applied their knowledge to anti-narcotics campaigns through social media. This is in line with the results of Primantari and Kahono's research (2013), that the anti-narcotics abuse campaign by using communication media can form a positive attitude and can be used as a warning to always stay away from drug abuse (drug awareness). 


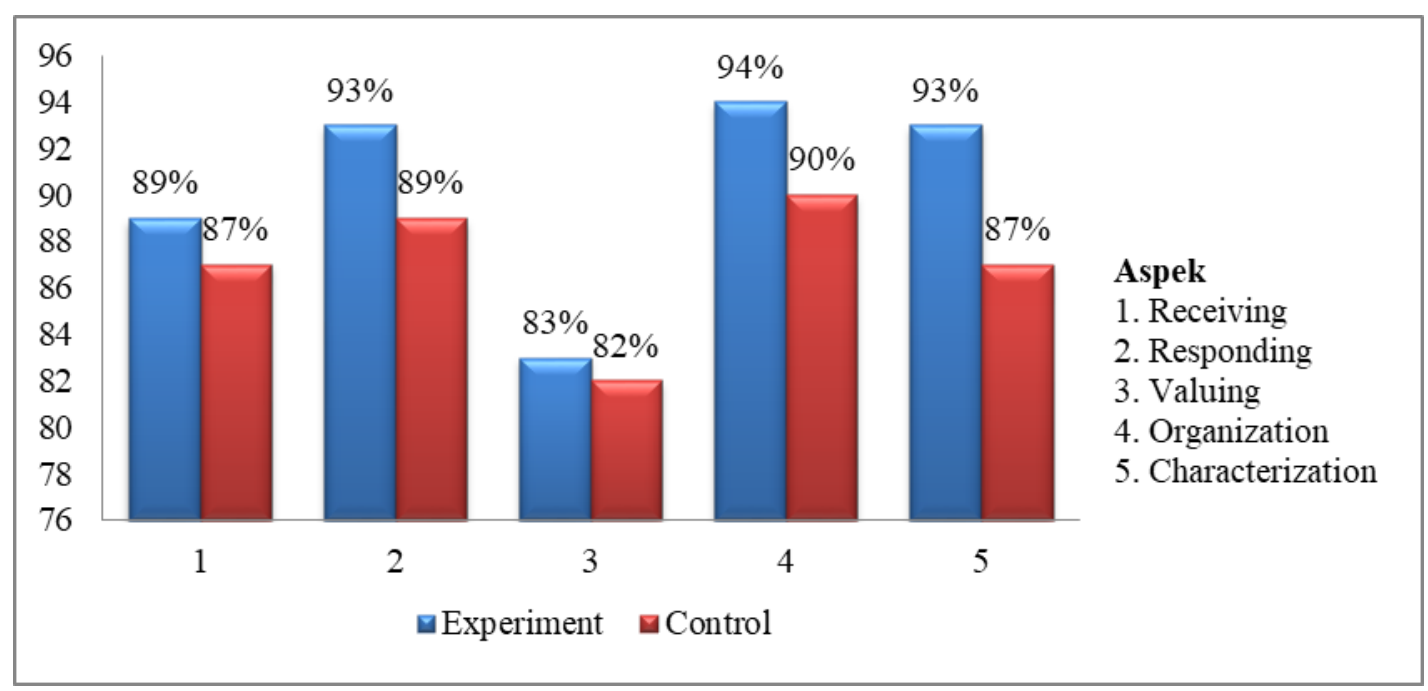

Figure 2. Percentage of Anti-Narcotics Attitudes of Students in Every Aspect.

Figure 2. not only shows the high anti-narcotics attitudes in the experimental and control groups in each aspect but also shows a slight difference in the percentages of the two groups. This difference was allegedly due to differences in the learning process in each group. In the control group, students get the concepts of the influence of drugs on the regulatory system from the teacher's explanation, while in the experimental group students get these concepts from the process of exploring cases of death/damage to the regulatory system due to drug consumption. Furthermore, students in the experimental group analyzed the cases they obtained using the worksheets provided by the teacher.

Based on the description above, the results can be obtained that the guided discovery learning model can develop an attitude of curiosity and anti-narcotics attitude of MIA class IV semester students of SMA Negeri 1 Salatiga. The results of filling in the student questionnaire showed that there were obstacles in the application of guided discovery learning. Guided discovery learning takes a long time. Students assume that the time given to explore information is limited. Students feel less satisfied with the information obtained. Even though students can complete every task given by the teacher. This indicates that students' curiosity is increasingly developing information to construct knowledge.

\section{Conclusion}

The conclusions in the study include: (1) there is a significant difference in the scores of curiosity attitudes, and anti-narcotics attitude scores between guided discovery learning and direct instruction model learning; (2) guided discovery learning is effective in completing the average score of curiosity attitudes and the average score of anti-narcotics attitudes $\geq 3.00$. Thus, based on the results of the study it can be concluded that guided discovery learning is effective in completing the learning outcomes of curiosity and anti-narcotics attitudes on the regulatory system concept. 


\section{References}

Alfiraida, S. 2018. Identifikasi materi biologi SMA sulit menurut pandangan siswa dan guru SMA se-Kota Salatiga. Journal of Biology Education. 1(2): 209-222.

Anwar, H. 2009. Penilaian sikap ilmiah dalam pembelajaran sains. Jurnal Pelangi Ilmu. 2(5): 102-114.

Binson, B. 2009. Curiosity Based Learning (CBL) program. US-China Education Review, 12 (6):13-22.

Jacobsen, DA., Eggen, P., \& Kauchak, D. 2009. Metode-metode Pengajaran. Terjemahan Akhmad Fawaid \& Khoirul Anam. Yogyakarta: Pustaka Belajar.

Kennedy, D. Hyland, A., \& Ryan N. 2007. Writing and using learning outcomes: A practical guide. EUA Bologna Handbook. 3(4-1): 1-30.

Krathwohl, DR. 2002. A Revision of Bloom's Taxonomy: An Overview. Theory Into Practice. 41(4): 212-218.

Laelasari, I \& Adisendjaja, Y.H. 2018. Mengeksplorasi kemampuan berpikir kritis dan rasa ingin tahu siswa melalui kegiatan laboratorium inquiry sederhana. Thabiea: Journal of Natural Science Teaching. 1(1): 14-19.

Melani, R., Harlita, \& Sugiharto, B. 2012. Pengaruh metode guided discovery learning terhadap sikap ilmiah dan hasil belajar kognitif biologi siswa SMA Negeri 7 Surakarta tahun pelajaran 2011/2012. Jurnal Pendidikan Biologi. 4(1): 97-105.

Permendikbud. 2014a.Peraturan Menteri Pendidikan dan Kebudayaan No. 59 tentang Kurikulum SMA. Jakarta: Kementerian Pendidikan dan Kebudayaan Republik Indonesia.

Permendikbud. 2014b. Peraturan Menteri Pendidikan dan Kebudayaan No. 104 tentang Pedoman Penilaian Hasil Belajar oleh Pendidik tentang Penilaian Hasil Belajar oleh Pendidik pada Pendidikan Dasar dan Pendidikan Menengah. Jakarta: Kementerian Pendidikan dan Kebudayaan Republik Indonesia.

Primantari, VA \& Kahono, GB. 2013.Efektivitas kampanye anti penyalahgunaan narkoba terhadap pengetahuan dan sikap remaja akan bahaya penyalahgunaan narkoba.Jurnal Sociologie1(2): 93-97.

Raida, SA. 2017. Penerapan pembelajaran guided discovery terhadap hasil belajar siswa SMA. Jurnal Genetika. 1 (1): 61-77.

Salirawati, D. 2012. Percaya diri, keingintahuan, dan berjiwa wirausaha: tiga karakter penting bagi peserta didik. JPK. 2(2): 213-224.

Utami, YL. 2014. "Pengembangan Instrumen Pengukuran Nilai Karakter Rasa Ingin Tahu (Curiosity) dan Rasa Tidak Mudah Percaya (Skepticism) pada Kegiatan Belajar Mengajar Biologi”. Skripsi. Semarang: Unnes. 